\title{
Trade Integration and Business Cycle Synchronization: Empirical Study of ASEAN-5, China, Japan, Korea, and India*
}

\author{
Etty Puji Lestari \\ Open University of Indonesia, Jakarta, Indonesia
}

\begin{abstract}
The lowering of tariffs in East Asian countries that started in the 1980s has accelerated this trend of increasing trade worldwide. From a theoretical point of view, however, the increased trade across trading patners can cause their business cycles to move in either direction, towards convergence or divergence. The aim of this research is to understand that business cycle syncronization in ASEAN-5 countries, namely, Indonesia, Malaysia, Thailand, Philipines, and Singapore, was influenced by increasing trade integration with China, Japan, Korea, and India. This is relevant for not only a better understanding of the influence of important trading patners on the business cycle fluctuations in the domestic economy, but also an important implication in terms of evaluating benefits of macroeconomic coordination. The result of regression model shows that intra industry trade is the major channel, by which the business cycles of China, Japan, Korea, and India become more synchronized with that of the ASEAN-5 economies. This result has important implications for the prospects for a unified currency in the region. The author expects that the costs to member countries of joining a currency union will be severely diminished, only when intra industry trade is predominant in the trade region as a whole after the currency union is formed.
\end{abstract}

Keywords: trade integration, business cycle, synchronization, international trade, intra industry trade, policy coordination

\section{Introduction}

The volume of trade in East Asian countries has been continuously increased in the last 20 years. Tariff reduction that started in the 1980s has accelerated this trend of increasing trade worldwide. The growth in trade in East Asian countries, however, has accelerated faster than that of any other region. Several studies have concluded that this rapid increase in trade is one of the key factors behind the region's more rapid growth in income (Shin \& Wang, 2003). Another important implication of the increased trade is that countries engaging in heavier trade integration are becoming more closely linked with regard to their macroeconomic performance. Thus, the influence of important trading partners is an essential factor in understanding the business cycle fluctuations of domestic economies.

Trade integration is one form of economic integration. Theoretically, trade integration will increase the trade intensity, economic efficiency, and high competitiveness which in turn will improve welfare. The increase

\footnotetext{
* Acknowledgement: Author would like to thank to Directorate General of Higher Education, Ministry of Education Indonesia for financial support in Hibah Doktor scheme and Professor Bob Jerome (University of Maryland University College) for the very useful comments to this paper.

Etty Puji Lestari, Dr., Department of Economics, Open University of Indonesia.

Correspondence concerning this article should be addressed to Etty Puji Lestari, Department of Economics, Open University of Indonesia, Jakarta, Indonesia. E-mail: ettypl@ut.ac.id.
} 
of trade integration on the synchronization of business cycles between the two countries depends on the dominance of inter- and intra-industrial trade. Interstate commerce which is supported by the availability of the similar production factors is called intra-industry trade, while trade with different production factors is called inter-industry trade. The greater the inter-industry trade is, the lower the business cycles correlation between trading partners will be (Zebregs, 2004).

\section{The Case of ASEAN}

The Association of South East Asian Nation (ASEAN) was established in Bangkok in 1967, as one driver of the economic integration in the Southeast Asia. It initially included five members, known as the ASEAN-5, namely, Indonesia, Malaysia, Philippines, Thailand, and Singapore. Brunei Darussalam then joined on January 7, 1984, Vietnam on July 28, 1995, Lao PDR and Myanmar on July 23, 1997, and Cambodia on April 30, 1999, which made today the 10 Member States of ASEAN. Since the establishment of ASEAN as a regional organization, the members have put economic cooperation as one of the main agenda items. In the beginning, the economic cooperation was focused on preferential trade, joint ventures, and complementation schemes between the governments of ASEAN countries and the private parties in the ASEAN region, such as the ASEAN Industrial Projects Plan (1976), Preferential Trading Arrangement (1977), ASEAN Industrial Complementation Scheme (1981), ASEAN Industrial Joint-Ventures Scheme (1983), and Enhanced Preferential Trading Arrangement (1987).

During 1980s and 1990s, when countries in various parts of the world began to remove the economic barriers, ASEAN countries realized that the best way to cooperate was to open their economies and create regional economic integration. ASEAN economic integration is intended to enhance the economic growth of ASEAN countries as well as to counteract the other economic blocs. At the 5th ASEAN Summit in Singapore in 1992, the framework agreement on enhancing ASEAN economic cooperation was signed, to mark the ASEAN Free Trade Area (AFTA) that began on January 1, 1993 with the Common Effective Preferential Tariff (CEPT) as the main mechanism. The establishment of AFTA influenced the form of tariff reduction and elimination, barriers of non-tariff removal, and the improvement of trade facilitation policies. During its development, AFTA had not only focused on the liberalization of trade in goods, but also on the services and investment (ASEAN Secretariat, 2008).

The 9th ASEAN Summit in Bali in 2003 agreed on the establishment of the ASEAN Economic Community (AEC) as one of the pillars of ASEAN. AEC aims to create a single market and production base marked by the free flow of goods, services, investment, skilled labor, and capital assets. The summit also set the priority sectors to be integrated, such as agricultural products, automotive, electronics, fisheries, rubber derived products, textiles and garments, wood derived products, air transportation, e-ASEAN (ITC), health, and tourism. The 10th ASEAN Summit in Vientiane in 2004, agreed on the Vientiane Action Program (VAP) as a guide to achieve the implementation of the AEC in 2020.

The 12th ASEAN Summit in Cebu in January 2007 issued a Declaration on the Acceleration of the Establishment of an ASEAN Community by 2015. In that context, the ASEAN Economic Ministers instructed the ASEAN Secretariat to develop a blueprint of the ASEAN Economic Community (AEC). This blueprint contains a strategic work plan in the short, medium and long term until the year of 2015 to support the establishment of ASEAN economic integration. The work plan objectives include:

- develop a single market and production base (free trade for goods, services, investment, skilled workers, and capital); 
- develop regional economic competitiveness (regional competition policy, IPRs action plan, infrastructure development, ICT, energy cooperation, taxation, and the development of SMEs);

- develop an equitable economic development region (region of equitable economic development) through the development of SMEs and Initiative programs for ASEAN Integration (IAI);

- develop global economic integration (a coherent approach in external economic relations to encourage the global supply network participation).

The unification of ASEAN as an economic community is expected to bring great changes, especially from an economic standpoint. This unification creates a market that covers 4.5 million $\mathrm{km}^{2}$ areas with a population of about 500 million people (equivalent to the current European Union), more than 720 billion dollars per year total trade and more than 737 billion dollars gross domestic product (GDP) (Achsani, 2008). The Table 1 indicates the amount of intra ASEAN-5 trade in both dollars and percentages of each member, after the last member, Cambodia, joined in 1999.

As shown in Table 1, the free trade agreement increased the intra-ASEAN-5 trade, from 122.24 billion dollars in 1995 to 415.37 billion dollars in 2008, or with average growth of 16.97 percent per year (ASEAN Secretariat, 2009). The intra-ASEAN-5 trade value was not evenly distributed, because it was dominated by Singapore which represented more than 40 percent of the total intra-ASEAN trade-5. This suggests that the economic benefit as ASEAN-5 was still not evenly distributed. The unification of ASEAN into the ASEAN Economic Community was also intended to reduce economic disparities in ASEAN countries. The tariff reduction agreement between East Asia countries in the 1980's gave a positive signal for all countries to increase the volume of trade (Rana, 2007). This condition affects a trade integration increase, especially for countries that had economically integrated such as ASEAN. One indicator is the increase of Gross Domestic product/GDP of ASEAN countries.

Table 1

Intra ASEAN-5 Trade, 1995-2008 (billion U.S. \$)

\begin{tabular}{|c|c|c|c|c|c|c|}
\hline Year & Indonesia & Malaysia & Philippines & Thailand & Singapore & ASEAN-5 \\
\hline 1999 & $\begin{array}{r}13,061.9 \\
(10.03)\end{array}$ & $\begin{array}{r}34,297.9 \\
(26.34)\end{array}$ & $\begin{array}{r}9,450.1 \\
(7.26)\end{array}$ & $\begin{array}{r}17,889.3 \\
(13.74)\end{array}$ & $\begin{array}{l}55,510.3 \\
(42.63)\end{array}$ & $130,209.5$ \\
\hline 2000 & $\begin{array}{r}17,664.9 \\
(10.80)\end{array}$ & $\begin{array}{r}40,343.5 \\
(24.67)\end{array}$ & $\begin{array}{r}10,938 \\
\quad(6.69)\end{array}$ & $\begin{array}{r}23,518.6 \\
(14.38)\end{array}$ & $\begin{array}{r}71,075.3 \\
(43.46)\end{array}$ & $163,540.3$ \\
\hline 2001 & $\begin{array}{r}15,233.9 \\
\quad(10.47)\end{array}$ & $\begin{array}{r}36,278.4 \\
(24.92)\end{array}$ & $\begin{array}{r}9,650.8 \\
(6.63)\end{array}$ & $\begin{array}{r}22,596.4 \\
(15.52)\end{array}$ & $\begin{array}{r}61,806.4 \\
(42.46)\end{array}$ & $145,565.9$ \\
\hline 2002 & $\begin{array}{l}16,929 \\
\quad(10.89)\end{array}$ & $\begin{array}{r}39,372.2 \\
\quad(25.32)\end{array}$ & $\begin{array}{r}11,071.7 \\
(7.12)\end{array}$ & $\begin{array}{l}23,718 \\
\quad(15.25)\end{array}$ & $\begin{array}{l}64,404 \\
\quad(41.42)\end{array}$ & $155,494.9$ \\
\hline 2003 & $\begin{array}{r}18,755.7 \\
(9.41)\end{array}$ & $\begin{array}{l}47,039.3 \\
(23.60)\end{array}$ & $\begin{array}{r}12,979.8 \\
(6.51)\end{array}$ & $\begin{array}{r}29,199.3 \\
(14.65)\end{array}$ & $\begin{array}{r}91,328.4 \\
(45.82)\end{array}$ & $199,302.5$ \\
\hline 2004 & $\begin{array}{r}24,680.3 \\
(10.09)\end{array}$ & $\begin{array}{l}57,928.2 \\
(23.69)\end{array}$ & $\begin{array}{r}15,193.7 \\
(6.21)\end{array}$ & $\begin{array}{r}37,004.6 \\
(15.14)\end{array}$ & $\begin{array}{r}109,678.6 \\
(44.86)\end{array}$ & $244,485.4$ \\
\hline 2005 & $\begin{array}{r}33,153.2 \\
\quad(11.65)\end{array}$ & $\begin{array}{r}65,797.7 \\
(23.13)\end{array}$ & $\begin{array}{r}16,024.2 \\
(5.63)\end{array}$ & $\begin{array}{r}45,419.4 \\
\quad(15.96)\end{array}$ & $\begin{array}{r}124,125.1 \\
(43.63)\end{array}$ & $284,519.6$ \\
\hline 2006 & $\begin{array}{r}37862.3 \\
(11.61)\end{array}$ & $\begin{array}{r}73,270.2 \\
\quad(22.47)\end{array}$ & $\begin{array}{r}18,410.5 \\
(5.65)\end{array}$ & $\begin{array}{l}50,484 \\
\quad(15.48)\end{array}$ & $\begin{array}{r}146,102 \\
(44.80)\end{array}$ & $326,129.0$ \\
\hline 2007 & $\begin{array}{l}46,084.2 \\
\quad(12.51)\end{array}$ & $\begin{array}{r}82,611.5 \\
\quad(22.43)\end{array}$ & $\begin{array}{r}20,907 \\
\quad(5.68)\end{array}$ & $\begin{array}{r}57,864.8 \\
(15.71)\end{array}$ & $\begin{array}{r}160,853.6 \\
(43.67)\end{array}$ & $368,321.1$ \\
\hline 2008 & $\begin{array}{r}68,162.5 \\
(16.41)\end{array}$ & $\begin{array}{r}85,076.7 \\
(20.48)\end{array}$ & $\begin{array}{r}21,398.4 \\
(5.15)\end{array}$ & $\begin{array}{r}69,375.3 \\
(16.70)\end{array}$ & $\begin{array}{r}171,355.4 \\
(41.25)\end{array}$ & $415,368.3$ \\
\hline
\end{tabular}

Note. Source: ASEAN Statistical Yearbook, 2009. 
Figure 1 shows that the overall GDP of the ASEAN countries has been increased. The GDP increase cannot be separated from the improvement of economic structure in ASEAN countries, investment climate and cooperation, especially trade cooperation. Nevertheless, GDP declined during the economic crisis in 1998, but it rose from the economic downturn which can be indicated by the increase of GDP.

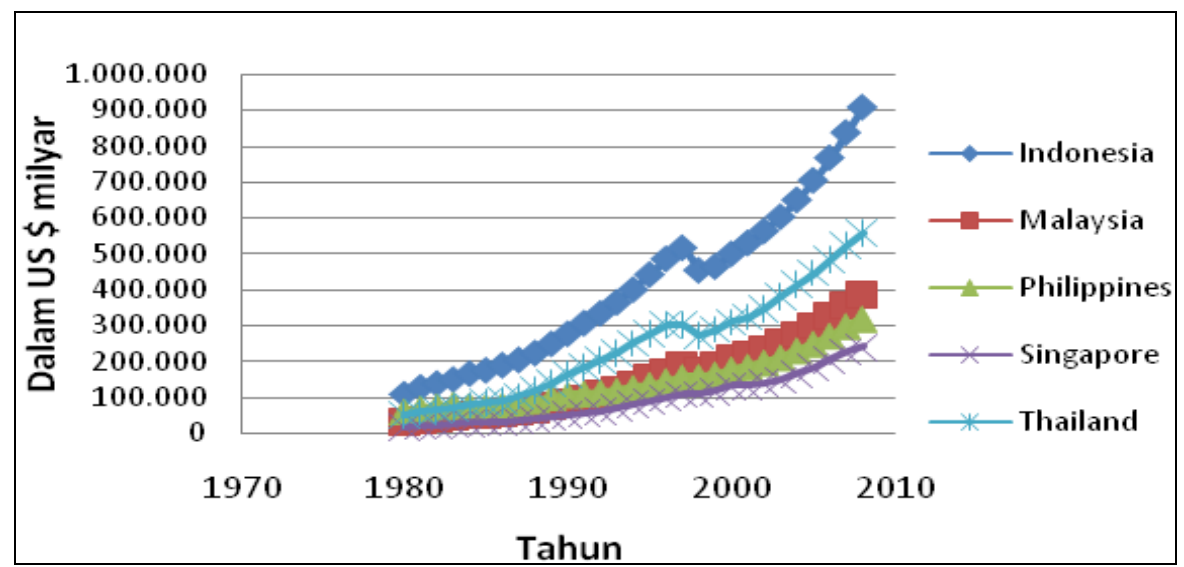

Figure 1. GDP of ASEAN-5 (in \$U.S. billion).

Figure 2 shows the economic growth in ASEAN-5. Before the 1997's economic crisis, the economic growth of the fifth ASEAN countries was very good, and Malaysia achieved the highest growth rate of 10 percent. Later, the condition changed when the financial crisis affected Thailand and other ASEAN countries, including Indonesia. Indonesia's economic performance reached the worst point with negative economic growth rate of 13.1 percent followed by Thailand, a negative of 10.5 percent. In 1997, during the recovery period, the economic performance of Thailand was better than that of Indonesia.

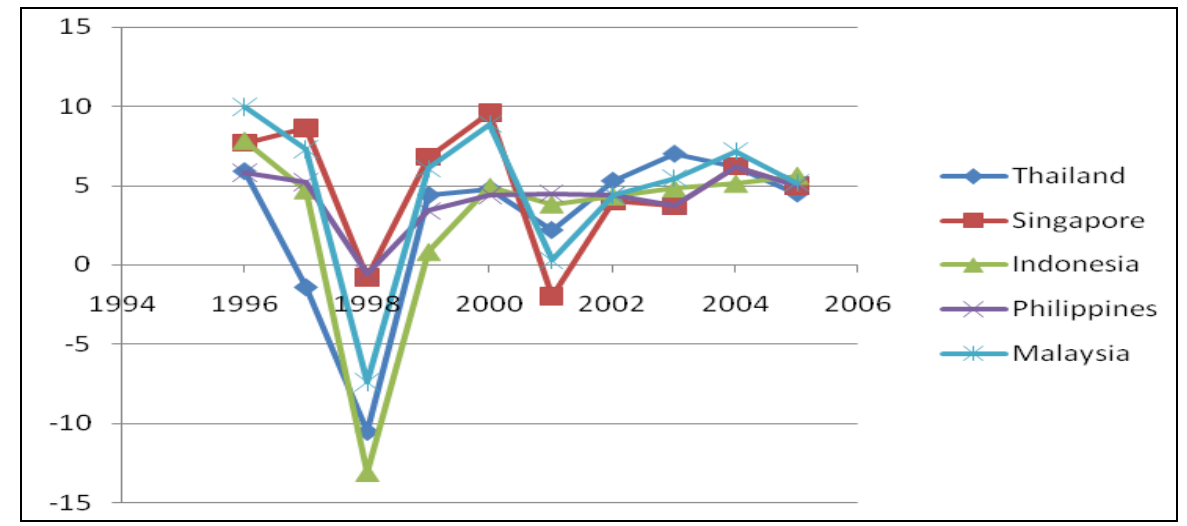

Figure 2. Average Economic Growth ASEAN-5. Source: ASEAN Secretariat (2008). Notes: In 1996-2000, Indonesia used GDP growth which was using the base year of 1993. Economic growth in 2001-2005 was obtained from the ASEAN FMSU using 2000 as base year; and Data obtained from the Singapore calculations using 2000 as base year.

\section{Trade and Business Cycles}

By 1999, Thailand had improved its economic performance which can be seen from the increase of its economic growth to 4.4 percent. This success was supported by the improvement of real sectors in Thailand. Meanwhile, Indonesia also had increased its economic growth to 0.8 percent, lower than the previous years but an improvement due to the worst of the crisis. The trade statistics of ASEAN also showed a rapid increase, 
especially after the introduction of tariff reduction in the 1980's (Rana, 2007; Shin \& Wang, 2003). During 1980 to 1990, the trade integration between countries showed its highest performance. The synchronization issue became very important, because the intensity of trade in ASEAN was increasing and so does the business cycle.

Figure 3 shows the ASEAN trade statistics with 10 trading partners in 2006. Based on the figure, the author finds out that the largest share of trade was between ASEAN members which reached 31 percent. The second position was done between ASEAN with Japan, the United States and European Union (14 percent). Other ASEAN trading partner was China (12 percent), then Korea (5 percent), Australia (3 percent), and India (3 percent). The figure also shows that ASEAN trade activities in Asia, especially with East Asian countries have been increased rapidly. The ASEAN trade activities especially with East Asian countries, is increasing. Some studies claim that the rapid increase in trade will push the revenue growth. The important implication of the trade increase to the country that's economically integrated was better macroeconomic performance than those who did not do the economic integration. The significant impact of trading partners became an essential factor to determine the business cycle fluctuations in the domestic economy (Shin \& Wang, 2003).

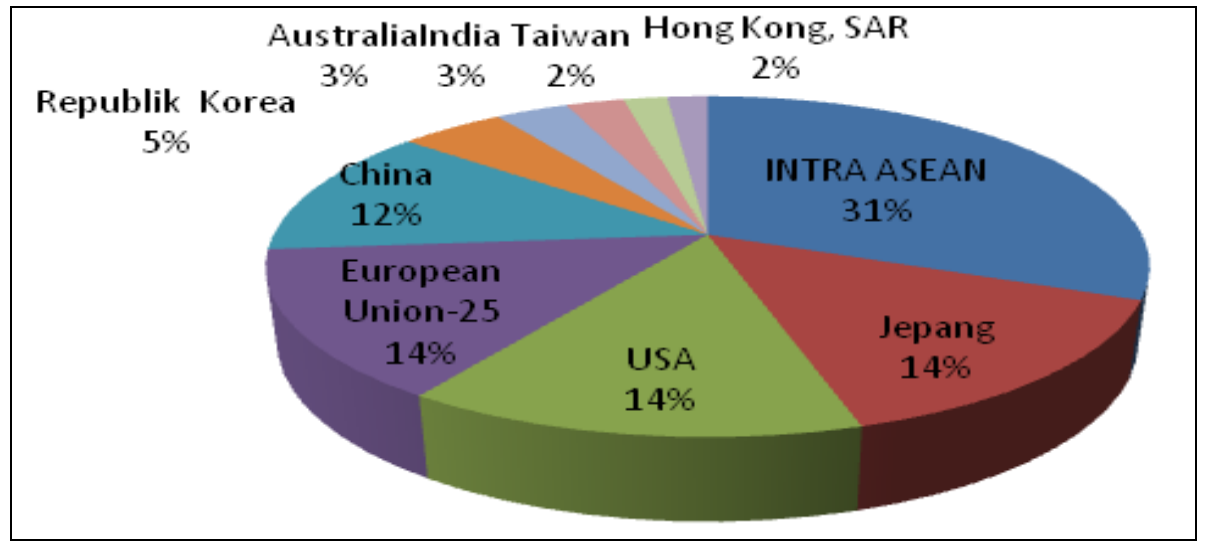

Figure 3. ASEAN trade value by partner countries, 2006.

From a theoretical point of view, however, the increased trade across trading partners can cause their business cycles to move in direction towards either convergence or divergence. For example, if trade occurs mainly like Heckscher-Ohlin or is of the Ricardian type, greater specialization would induce the industrial structures of the trading countries to diverge, resulting in less synchronized movements of their business cycles. In contrast, if the increased trade occurs mainly through intra-industry trade, this conclusion would be overturned, and the business cycles of the trading partners would become more synchronized (Frankel \& Rose, 1998; Rana, 2007; Shin \& Wang, 2003; Teng \& Way, 2005).

Business cycle movement has an impact on the economic and institutional policy. Many researchers believe that there is a strong correlation between the trade integration and the business cycle. Several studies have analyzed the movements of macroeconomic aggregates experienced by a country that was economically integrated with other nations. There are three general discussion of the analysis (Loayza, Humberto, \& Angel, 2001). First, a shock which was faced by a country will usually influence the other countries through the trade integration and money market transactions. Second, when countries are integrated in a group, if one member experiences an economic shock, it will impact the other countries in the group. Third, the shock that hit a particular sector may result in movements in output aggregate, if the country has the same economic structure. 
Research on the business cycle that has been done by many researchers also has some research gaps. Research by Eichengreen (1991), Kenen (1969), and Krugman (1993) found that the increase in trade networks will lead to more specialization in the production and the reduced impact on the synchronization of the business cycle, when the business cycle shock was influenced by technology (industry-specific technological shock). These empirical results were supported by Eric (2007) who had has three important findings. First, the vertical trade specialization has a positive impact on the business cycle synchronization. This finding indicated that the strength of the bilateral trade activities network will generate more demand and supply between countries that tend towards business cycle synchronization. The second finding was that intra industry trade did not have a significant impact on the synchronization of business cycles. This reflects that the intra-industry trade was horizontal where the trade of goods has the same process between industries. This is the opposite effect of business cycle synchronization. The third finding was from a study conducted by Eric that the intensity of the trade itself has a negative impact on the business cycle synchronization. This shows that if bilateral trade is getting stronger, there will be more industrial specialization and resource turnover between countries which caused a lack of business cycle synchronization.

Different results were found in a study conducted by Frankel and Rose (1998). They claimed that intra-industry trade was more prominent than inter-industry trade. As a result, the business cycle which would be positively correlated as trade becomes more integrated. In a subsequent study, they said that there were two important networks from positive relationships between the movements of business cycles and the increase of trade. First, if there is a demand boom in a country, it can affect the trading partners since the states' growth rate will depend on the import volume increases. Second, trade increases will cause the increase of fiscal and monetary policy coordination. If the two policies were followed, it will impact business cycle synchronization between trading partners. These networks had implications on the trade increase and the strength of the movement of business cycles. Based on a sample of 21 industrial countries, they concluded that the higher the level of intra-industry trade is, the larger the correlation of business cycles will be.

The study of Fidrmuc (2001) which used cross section analysis in OECD countries between 1990 and 1999, found that there was no convergent relationship between intra-industry trades with the business cycle, and there was no direct relationship between the business cycle with the intensity of bilateral trade. Loayza, Humberto, and Angel (2001), who analyzed East Asian countries, found that there was a relationship between short-term and long-term business cycle movements. They concluded that business cycles synchronization is based on the number of similarity of trade structures. Shin and Wang (2003) found that intra industry trade was the main factor which affects business cycle synchronization in South Korea and 11 countries in Asia. The results of empirical studies concluded that the business cycles will be more synchronous if the trade increase was dominated by intra industry trade.

\section{Model Specification, Data, and Methodology}

To measure output co-movements, annual data were collected on real GDP for nine Asian countries over the period of 1980-2008. The countries considered are three East Asian countries (China, Japan, and Korea), five ASEAN countries (Indonesia, Malaysia, the Philippines, Singapore, and Thailand) and one other Asian country (India). All the data are drawn from the IMF International Financial Statistics CD-ROM.

The trade volume data are from the IMF Direction of Trade Statistics CD-ROM. Industry-level trade data are available in Nicita and Olarreaga (2001), in which the United Nations Statistics Department's Comtrade 
database is reorganized by using the World Bank's World Integrated Trade Solution (WITS) software. The industry disaggregation in the database follows the International Standard Industrial Classification (ISIC) and is provided for manufacturing industries at the two-digit level (nine industries). To investigate how the bilateral trade intensity in each pair of the nine Asian countries influence business cycle synchronization, a proxy was used for bilateral trade intensity, following Frankel and Rose (1998): $w t_{t}$. The variable $\left(w t_{t}\right)$ uses both export and import data. The variable is defined as follows:

$$
w t_{t}(i, j)=\frac{x_{i j t}+m_{i j t}}{X_{i t}+M_{i t}+X_{j t}+M_{j t}}
$$

where $X i_{j t}=$ total nominal exports from country $i$ to country $j$ during period $t$; $M i_{j t}=$ total nominal imports is from country $i$ to country $j$ during period $t$; and $X_{i t}$ and $M_{i t}\left(X_{j t}\right.$ and $\left.M_{j t}\right)$ denote total global exports and imports, respectively, for country $i(j)$ during period $t$. A higher value of any of these indexes indicates greater trade intensity between country $i$ and country $j$.

The trade intensity measure has a shortcoming in representing spillover effects, since it does not include information on the size of the trading partner. Given the same trade intensity, demand spillovers would be large for the larger trading partners. Hence, a new measure of demand spillovers that is the multiplication of trade intensity and the corresponding trading partner's output is constructed (Shin \& Wang, 2003).

A measure of intra-industry trade intensity is derived like Grubel and Lloyd (1975). In constructing the measure, an important consideration is how detailed a classification of industries should be. If the author wants to measure trade in more homogeneous sectors, the author needs to disaggregate industries further. As the industries are further disaggregated, however, the portion of intra-industry trade will shrink and eventually go to nil. Rather than determining a proper industry classification a priori was constructed based on two digit industry classifications that follow the ISIC. The constructed measure is:

$$
I T=1-\frac{\sum i\left|X_{i j t}^{k}-m_{i j t}^{k}\right|}{\sum i\left|X_{i j t}^{k}+m_{i j t}^{k}\right|}
$$

where $x_{i j t}^{k}$ is total nominal exports of product $k$ from country $i$ to country $j$ and $m_{i j t}^{k}$ is total nominal imports of product $k$ from country $j$ to country $i$. Depending on how an industry is classified, the author measures IIT-2 for two-digit classifications. Note that, since the second term on the right-hand side of equation decreases as more intra-industry trade occurs, the author subtracts it from 1 , so that the index will monotonically increase as intra-industry trade increases.

In general, there should also exist a causal effect of intra-industry trade on business cycle synchronization. In particular, monetary and fiscal policy shocks also have a direct impact on business cycle synchronization. If greater intra-industry trade makes it necessary to cooperate more in terms of policy, the omission of policy shocks can generate a spurious result. Thus, the effects of policy shocks are included to investigate whether intra-industry trade is still an important factor for business cycle co-synchronization. The ratio of budget deficit to GDP for each country was used to calculate the correlation coefficient of this ratio across each pair of countries which are used as a measure of the degree of fiscal policy coordination (Teng \& Way, 2005).

And, the correlation coefficient of bilateral interest rates across each pair of countries is used as the degree of monetary policy coordination (Rana, 2007). Another policy effect is included to examine the effect of the exchange rate policy on the business cycle co-movements. Bilateral exchange rates of paired countries are used 
as the degree of exchange rate policy coordination.

To analyze this relationship more formally, the author estimates the following equation that is used:

$$
B C(i, j)_{t}=\alpha_{0}+\alpha_{1} T I(i, j)_{t}+\alpha_{2} \operatorname{IIT}(i, j)_{t}+\alpha_{3} \operatorname{FPC}(i, j)_{t}+\alpha_{4} \operatorname{MPC}(i, j)_{t}+\alpha_{5} E R(i, j)_{t}+\varepsilon_{i j t}
$$

where $B C$ refers to the correlation of output between country $i$ and country $j$ during period $t$; TI refers to trade intensity; and IIT refers to intra-industry trade at the 2-digit level. For fiscal policy coordination (FPC), the author calculates the correlation of the ratio of budget deficit to GDP between country $i$ and country $j$. The correlation coefficient of the bilateral interest rates across each pair of countries is used to calculate monetary policy $(M P C)$ coordination. The bilateral exchange rate of paired countries is used as the degree of exchange rate policy coordination $(E R)$.

\section{Results and Discussions}

The results of these calculations are divided into trade variables and policy variables. Trade variables consist of trade intensity and intra industry trade, while the policy variables consist of monetary policy coordination, fiscal policy coordination, and exchange rate policy. The data were calculated by pooled least squared method/PLS. It showed that only intra industry trade has a positive and significant impact on the business cycles synchronization (see Table 2). Meanwhile, other variables, such as the intensity of trade, fiscal policy coordination, monetary policy coordination, and exchange rate policy have a negative impact on the business cycles synchronization.

Table 2

The Result of Panel Regression

\begin{tabular}{lcc}
\hline Variable & \multicolumn{2}{c}{ Pooled least squares } \\
\cline { 2 - 3 } & coefficient & $t$-statistik \\
\hline Constant & 1.021693 & $(27.45743)^{*}$ \\
Trade Intensity/TI & -0.681727 & $(2.720828)^{*}$ \\
Intra Industry Trade /IIT & 0.185841 & $(-4.129601)^{*}$ \\
Fiscal Policy Coordination /FPC & -0.188147 & $(-5.906205)^{*}$ \\
Monetary Policy Coordination /MPC & -0.220358 & $(-2.415961)^{* * *}$ \\
Exchange Rate Policy/ER & -0.086541 & \\
Number of observation & 261 & \\
$R$-squared & 0.215097 & \\
\hline
\end{tabular}

Notes. ${ }^{*},{ }^{* *}$ and ${ }^{* * *}$, represent at $1 \%, 5 \%$, and $10 \%$ level of significance respectively.

The results of panel regression are showed that trade intensity has a negative impact on business cycles synchronization. This means that increasing trade intensity will have less influence on business cycle synchronization. These results are not consistent with the hypothesis that the intensity of trade has a positive influence on the synchronization of business cycles. One of the causes of this negative result was the small trade intensity between the five members of ASEAN with China, Japan, Korea, and India, if compared with the intensity of trade between ASEAN-5 countries themselves (see Figure 4). So far, the pattern of ASEAN trade is still dominated by trade among ASEAN countries. The condition is caused by several factors. The first factor is the barriers to trade between ASEAN-5 with their trading partners, namely, China, Japan, Korea, and India. Trade barriers are related to customs procedures, settlement of trade disputes and product standardization among other things. As a result, trade activity becomes inhibited. Agarwala and Prakash (2002) from the Asian 
Development Bank (ADB) stated that the intensity of trade growth in the decade of 1980-1990 was very small. Previous research also concluded that trade intensity gave negative results on business cycles synchronization (Teng \& Way, 2005; Eric, 2007).

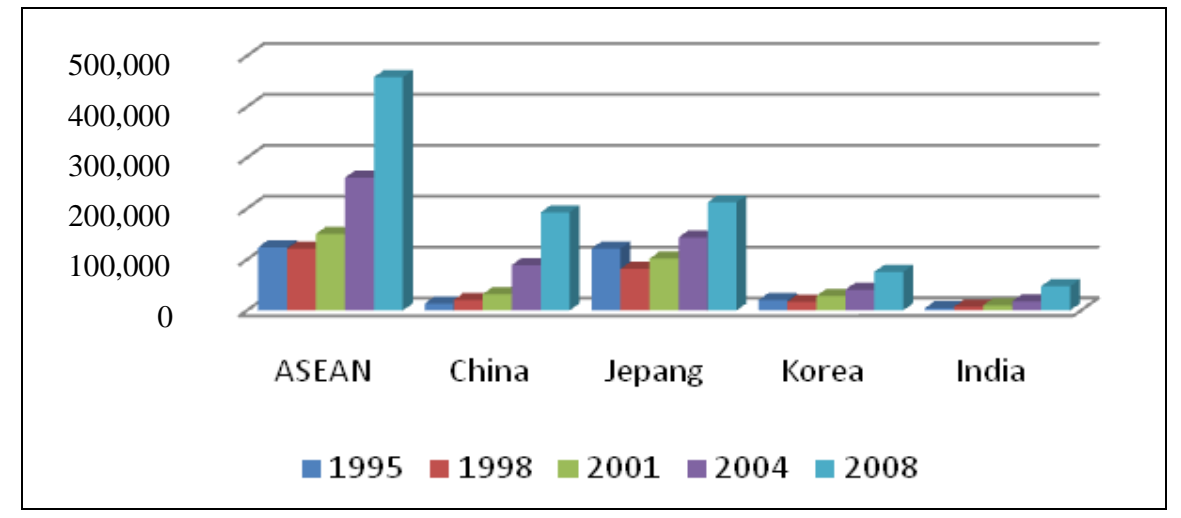

Figure 4. The intensity of the ASEAN trade with other countries.

The results for the intra industry trade variable showed that intra industry trade has positive impacts on business cycles synchronization. These results concluded that intra industry trade is an important factor that drives business cycles synchronization. These findings demonstrated that the existence of ASEAN-5 countries as trading partners of China, Japan, Korea, and India are very important, because they provide a strong impetus offer mutual trade benefits. Positive results are relevant to the empirical study conducted by Shin and Wang (2003), Teng and Way (2005), and Rana (2007) which stated that the increase of intra-industry trade will increase business cycle synchronization. Positive results are also supported by empirical studies conducted by Yuniarti (2007) who found that intra industry trade between ASEAN countries reached 96 percent of market share. This condition is driven by a number of multinational companies that invest in ASEAN countries. Studies conducted by Yuniarti (2007) stated that most of world trade, especially among industrialized countries in intra industry trade. This condition needs to be examined in the presence of product differentiation, scale industries, and the increasing market competition. One of the best export products in ASEAN countries is automotive components, which is one intra industry trade. The review that has been done by Trade and Management Institute/TDMI (2003) mentions that the increase of automotive component was supported by the reduction of production costs, low tariffs among the ASEAN members in order to support the ASEAN Free Trade Area/AFTA. This increase is also through the ASEAN Industrial Corporation scheme (AICO).

The calculation of fiscal policy variable indicates that this variable gives a negative impact on business cycle synchronization. Less business cycle synchronization is caused by differences in handling the fiscal policy. The implementation of fiscal policy in each country is internal and tends to be divergent. The challenge of handling the budget deficit problem was adjusted to the economic structure of each country. Due to its internal nature, the coordination of fiscal policy has not been carried out intensively. If the government's budget deficit is high, it will affect the vulnerability of an economy. Various strategies were undertaken to decrease the deficit, including tax reform reduction of foreign debt and increased domestic production. The objective of fiscal policy is to increase national production and economic growth, to expand employment, to reduce unemployment, and to decrease inflation (Suparmoko, 2000). 


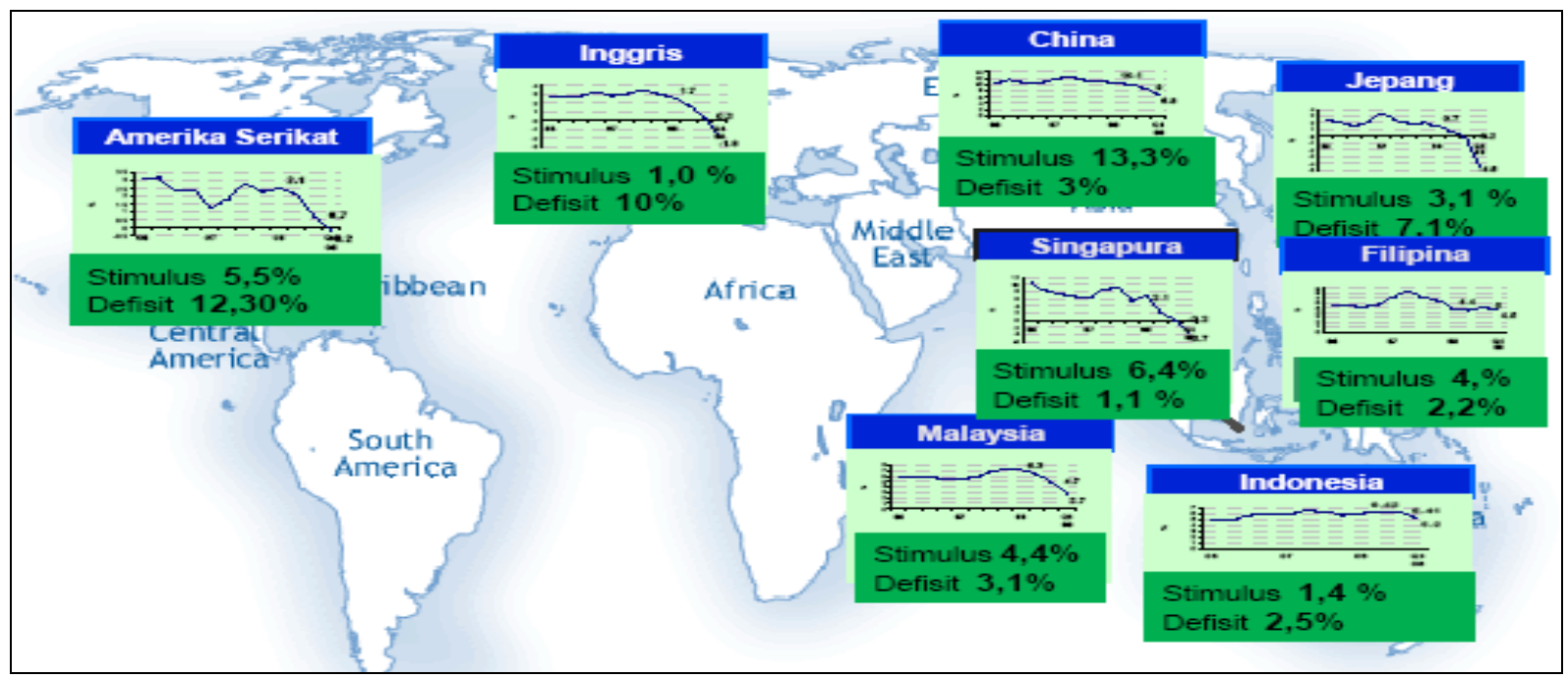

Figure 5. Fiscal stimulus in some countries. Source: Retrieved from http://www.fiskal.depkeu.go.id.

One strategy that has been done to overcome the deficit problem was by giving fiscal stimulus. Figure 5 describes the implementation of fiscal stimulus in some countries. G-20 gave fiscal stimulus to the countries which were experiencing budget deficits in the first phase in 2009-1.4 trillion dollars (Retrieved from http://www.fiskal.depkeu.go.id). In developing countries like Indonesia which has a budget deficit of 2.5 percent, fiscal stimulus was 1.4 percent, while developed countries like Japan which was experiencing a budget deficit of 7.1 percent given a fiscal stimulus of 3.1 percent. These results supported the research of Teng and Way (2005) who also found that fiscal policy coordination in the ASEAN-5 as well as India and China tends to lower the business cycle.

The results of the calculation for the monetary policy coordination show that the variable has a negative impact on business cycle synchronization. These negative results illustrate the instability that low monetary correlation between the countries. This unstable condition was due to the implementation of financial liberalization in ASEAN in the late 1970s. Interest rate liberalization was one of the most important financial reforms, especially in the four ASEAN countries, namely, Indonesia, Malaysia, Singapore, and Thailand. Except for Singapore, the interest rates often experienced a negative spread before the implementation of financial reforms.

After the banking deregulation in Indonesia in 1983, the time deposits multiplied and interest rates become positive spread. In Malaysia, the time deposits also increased rapidly after the deregulation of 1978, which marked the end of financial repression. The nominal and real interest rates increased the capital inflow from 1983 to 1988. In Thailand, despite the opening of financial repression in the early 1980s, the savings rate is still controlled by the government since the financial liberalization in 1989. Financial disclosure conditions which were experienced by the ASEAN countries may cause financial stability. That was caused by unsupported financial market infrastructure. Financial disclosure is characterized by the exemption ceiling of interest rates by monetary authorities causing the instability primarily related to interest rates (Laidler, 1985). This instability causes a low monetary correlation between ASEAN-5 countries, and therefore it will decrease business cycles synchronization. These findings are similar with Teng and Way's findings (2005).

The calculation on exchange rate policy coordination shows that the exchange rate policy has a negative impact on business cycles synchronization. These results indicate the importance of exchange rate stability in 
trade integration. Exchange rate volatility will increase the transaction costs that will create unfair competition between trading partners who have a weaker or depreciated currency (Fiess, 2005). This condition will cause a political backlash that impacts the bilateral import activities. Therefore, the stabilization of exchange rate policy is considered as an effective tool to resist political pressures that violate the agreement on trade integration. Exchange rate volatility that hit the economy during 1997 decreased the business cycle synchronization. At the beginning, the ASEAN and East Asia countries implemented various exchange rates system. These conditions changed drastically during the economic crisis. Malaysia then decided to adopt a fixed exchange rate system, while Indonesia replaced the earlier system with a free-floating exchange rate and other countries did financial intervention to stabilize their nominal exchange rate.

\section{Conclusions}

Increasing trade among Asian countries induces a higher degree of economic integration within the region. In this sense, the business cycle of a country is expected to be continuously influenced by other economies in Asia, especially as trade within the region grows relatively more important. The study concludes that intra-industry trade is the major channel, though which the business cycles of East Asian economies become synchronized. This may have important implications for the formation of a currency union. The author expects that the costs to member countries of joining a currency union will be severely diminished only when intra-industry trade is predominant in the trade region as a whole after the currency union is formed.

\section{References}

Achsani, N. A. (2008). Economic integration of ASEAN+3: Opportunities and threats. Retrieved from http:/www.brighten.or.id/index.php? view=article\&catid=40:noer-azam achsani\&id=64:integrasiekonomi-asean3-antara-peluang-dan-ancaman\&tmpl= component\&print= 1\&page=

Agarwala, R., \& Prakash, B. (2002). Regional cooperation in Asia: Long term progress, recent retrogression, and the way forward. ERD Working Paper Series No. 28, Asian Development Bank.

ASEAN Secretariat. (2008). ASEAN Selayang Pandang. ASEAN Secretariat Jakarta.

ASEAN Secretariat. (2009). ASEAN Statistical Yearbook 2008. ASEAN Secretariat Jakarta.

Bejan, M. (2007). Some business cycle consequences of trade agreement: The case of the North American Free Trade Agreement. EUI Working Paper. Robert Schuman Centre for Advanced Studies.

Cerro, A. M., \& Pineda, J. (2002). Latin American growth cycles: Empirical evidence 1960-2000. Estudios de Economía, 29(1), 89-109.

Choe, J. (2001). An impact of economic integration through trade: On business cycles for 10 East Asian countries. Journal of Asian Economics, 12(4), 569-86.

Christodoulakis, N., Dimelis, S. P., \& Kollintzas, T. (1995). Comparison of business cycles in the EC: Idiosyncrasies regularities. Economica, 62, 1-27.

Cortinhas, C. (2007). Intra industry trade and business cycle in Asean. Journal of Applied Economic, 39, 893-902.

Eichengreen, B. (1991, January). Is Europe an optimum currency area?. NBER Working Paper No. 3579. National Bureau of Economic Research, Cambridge.

Eric, C. Y. Ng. (2007). Vertical specialization, intra industry trade and business cycle comovement. Working Paper. Federal Reserve Bank of Mineapolis.

Escaith, H. (2004). La Integración Regional la Coordinación Macroeconómica en América Latina. Revista de la CEPAL, 82, 55-74.

Fidrmuc, J. (2001). The endogeneity of optimum currency area criteria, intra-industry trade and EMU enlargement. Bank of Finland Institute for Economies in Transition (BOFIT) Discussion Paper No. 8. Helsinki: Bank of Finland (Suomen Pankki).

Fiess, N. (2005). Business cycle synchronization and regional integration: A case study for central America. Working Paper. Retrieved from http://www.worldbank.org 
Frankel, J., \& Rose, A. (1998). The endogeneity of the optimum currency area criteria. Economic Journal, 108(449), 100-125.

Gruben, W., Koo, J., \& Millis, E. (2002). How much does international trade effect business cycle synchronization (Manuscript). Federal Reserve Bank of Dallas.

Grubel, H. G., \& Lloyd, P. J. (1975). Intra-industry trade: The theory and measurement of international trade in differentiated products. London: MacMillan.

Imbs, J., \& Romain, W. (2003). Stages of diversification. American Economic Review, 93(1), 63-86.

Jacobo, A. (2000). Some empirical evidence on the macroeconomic behavior of Mercosur Countries. In Supranational Cooperation and Integration, Goods and Services vs Information (pp. 127-152). Berlin: P. Lang Publishers.

Kenen, P. (1969). The theory of optimum currency area: An an eclectic view. In R. Mundell, \& A. Swoboda (Eds.), Monetary Problems in the International Economy. Chicago: University of Chicago Press.

Krugman, P. (1993). Lessons of massachusetts for EMU. In F. Torres, \& F. Giavazzi (Eds.), Adjustment and Growth in the European Monetary Union (pp. 241-261). Cambridge: Cambridge University Press.

Laidler, D. E. W. (1985). The demand for money: Theories, evidence and problems (2nd ed.). New York: harper and Row.

Loayza, N., Humberto, L., \& Angel, U. (2001). Comovement and sectoral interdependence: Evidence for Latin America, East Asia, and Europe. IMF Staff Papers, 48(2), 367-396.

Mejía-Reyes, P. (2003). No Linealidades ciclos económicos en América Latina. Zinacantepec: El Colegio Mexiquense, Universidad Autónoma del Estado de México.

Nicita, A., \& Olarreaga, M, (2001). Trade and production, 1976-99. Policy Research Working Paper Series 2701, The World Bank.

Rana, P. B. (2007). Trade intensity and business cycle synchronization: The case of East Asia. Working Paper Series on Regional Economic Integration No. 10. Asian Development Bank.

Shin, K., \& Wang, Y. (2003). Trade integration and business cycle synchronization in East Asia. Asian Economic Papers, 2(3), $1-20$.

Suparmoko, S. (2000). State financial in theory and practice (5th ed.). Indonesia: Badan Penerbit Fakultas Ekonomi Yogyakarta.

TDMI. (2003). Overview of indonesian trade. Jakarta: Trade and Management Development Institude.

Teng, K. K., \& Wai, C. C. (2005). Trade integration and business cycle synchronization: The case of India, China with ASEAN-5. Working Paper. Retrieved from http://www.pes.org.ph/faea/downloads/paper/3/pararell3b1.pdf

Yuniarti, D. (2007, August). Determinants analysis of Indonesian trade. Journal of Development Economics, 12(2), 99-109.

Zebregs, H. (2004). Intraregional trade in emerging Asia. IMF Policy Discussion Paper. 